\title{
Note
}

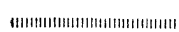

\section{Variation of Elemental Concentration in Hair in Relation to Diabetes ${ }^{\dagger}$}

\author{
Tarek ELNIMR \\ Physics Department, Faculty of Science, Tanta University, Tanta, Egypt \\ Received October 15, 1990
}

\begin{abstract}
With the help of reactor neutron activation analysis investigations of the trace elements such as copper, manganese, zinc, selneium, nickel, cadmium and mercury have been performed purposing to settle the problems of distinction between healthy persons and patients sffering from diabetes.

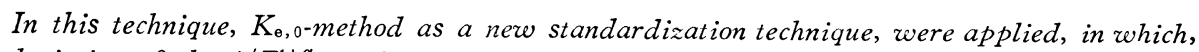
the deviation of the $1 / E^{1+\alpha}$ epithermal neutron flux distributions from $1 / E$ law, true coincidence effects of cascade $\gamma$-rays, and the efficiency of the Ge-detector were taken into consideration. Short lived nuclides were determined by a short activation with the help of a pneumatic irradiation facility and automatic correction of dead time and decay. The medium and long lived nuclides were determined after $48 \mathrm{~h}$ irradiation and ten days cooling. The patients headhair samples showed a significant differences in the $\mathrm{Cu}, \mathrm{Zn}, \mathrm{Se}$, and $\mathrm{Hg}$. The result indicates that early diagnosis by means of trace elements determination could be possible.
\end{abstract}

Key Words: diabetes, selenium, copper, zinc, mercury, hair, neutron activation analysis

\section{Introduction}

The awareness of the importance of trace metals in biological system continues to increase. In addition to the diseases related to trace element deficiencies or toxicity some trace metal variations have been observed between normal and diseased tissue ${ }^{1-6}$. These variations have not always been conclusive since the trace element variations observed between the different control (normal) specimens were as large as those between the normal and diseased tissues. The initial goal of this study was to obtain precise trace element concentrations for a carefully controlled group of samples to determine if trace elements reflected the genetic abnormalities in hair, and in addition, to the possible use of trace elements for diagnostic purposes.

The present study was undertaken to inves-

$\dagger$ 毛髪中の元素濃度の変化と糖尿病との関係。ター レック・エルスール：タンタ大学理学部物理学科, エジプト国タンタ市。 tigate the potential of hair as an indicator of total body trace element burden for normal and diseased persons and the investigation of possible correlations with the diabetes. Significant changes were observed for certain elements such as $\mathrm{Cu}, \mathrm{Zn}, \mathrm{Se}$ and $\mathrm{Hg}$. It was the aim of the present study to help in clarifying the issue and to extend the analysis to more elements.

$K_{\theta, 0}-$ Neutron activation analysis

The $K_{\theta, 0}$ method $^{(1-9)}$ differes from the relative method in its treatment of standards; it simplifies preparation, activation and measurement of individual standards through replacing them by the nuclear data. For this reason the method is advantageous over the relative method for multielement analysis of hair samples, because it precludes the problems involved in preparation of multielement standards in a condition similar to hair samples.

When applying the $K_{\mathrm{e}, 0}$-method to reactor 
neutron activation analysis (RNAA), the concentration of an element $\mathrm{i}$ can be calculated from the follwing equation;

$$
\begin{aligned}
\rho(x)= & \frac{\left[\frac{\left(N_{\mathrm{p}}\right)_{\mathrm{Cd}} / t_{\mathrm{m}}}{S D C}\right]_{\mathrm{samp} 1 \mathrm{e}}}{\left(A_{\mathrm{sp}}\right) \cdot K_{\mathrm{e}, 0}} \cdot \frac{F_{\mathrm{Cd} *}}{F_{\mathrm{Cd}}} \cdot \frac{\varepsilon_{\mathrm{p}} *}{\varepsilon_{\mathrm{p}}} . \\
& \frac{Q_{0 *(\alpha)}}{Q_{0 *}} \cdot \frac{G_{\mathrm{e}^{*}}}{G_{\mathrm{e}}} \cdot \frac{Q_{0}}{Q_{0(\alpha)}} \cdot 10^{6}
\end{aligned}
$$

where the asterisk refers to a comparator (weight $\mathrm{g}$ in gram) coirradiated with the sample. Other symbols are as follows:

$\rho$ : concentration $(\mathrm{ppm})$ for an element in a sample

$A_{\mathrm{sp}}:$ specific activity of the measured $\gamma$ peak;

$$
A_{\mathrm{sp}}=\frac{A_{\mathrm{p}}}{S D C}
$$

where $A_{\mathrm{p}}$ is the measured average activity of the full energy peak $A_{\mathrm{p}}=N_{\mathrm{p}} / t_{\mathrm{m}}$ with $N_{\mathrm{p}}$ the measured number of net counts under the full-energy peak.

$\left(N_{\mathrm{p}}\right)_{\mathrm{Cd}}$ : measured number of net counts under the full energy peak of the monitor irradiated under cadmium cover

$D$ : decay factor, with $t_{\mathrm{d}}$ the decay period

$C$ : measurement factor correcting for decay during the measured period $t_{\mathrm{m}}$;

$$
\begin{aligned}
& C=\frac{1-\exp \left(-\lambda t_{\mathrm{m}}\right)}{\lambda t_{\mathrm{m}}} \\
& K_{\mathrm{e}, 0}=\frac{\left(A_{\mathrm{sp}}\right)_{\mathrm{Cd}}}{\left(A_{\mathrm{sp}}\right)_{\mathrm{Cd}}} \cdot \frac{F_{\mathrm{Cd}} *}{F_{\mathrm{Cd}}} \cdot \frac{\varepsilon_{\mathrm{p}} *}{\varepsilon_{\mathrm{p}}}
\end{aligned}
$$

$F_{\text {Cd }}$ : cadmium epithermal neutron transmission factor ${ }^{10)}$

$\varepsilon_{p}$ : absolute full-energy peak efficiency of the detector for the measured $\gamma$-line ${ }^{11}$

$Q_{0}$ : resonance integral to cross-section at $2200 \mathrm{~m} / \mathrm{s}$;

$$
\begin{aligned}
& Q_{0}=I_{0} / \sigma_{\text {th }} \\
& Q_{0}(\alpha)=\frac{Q_{0}-0.429}{\left(\bar{E}_{\mathrm{r}}\right)}+\frac{0.429}{(2 \alpha+1)(0.55)^{\alpha}}
\end{aligned}
$$

$\bar{E}_{\mathrm{r}}$ : effective resonance energy ${ }^{12), 13)}$

$G_{0}$ : epithermal neutron self-shielding ${ }^{14)}$

$\alpha$ : deviation parameter from the $1 / E$ shape.

\section{Experimental}

Head hair samples were collected from 16 male and 55 female patients and also 5 male and 5 female control subjects.

All patients and control subjects live in Mekka, Saudi Arabia. The hair samples were washed with acetone and bidistilled water, according to the procedure recommended by the IAEA Advisory Group ${ }^{15)}$. After a final wash with acetone the samples were air-dried at room temperature. To determine the elements producing nuclides with short and long half lives, samples as well as comparator (AuAl wire) were irradiated in polyethylene vials for two irradiation times in the Thetis reactor of the Rijksuniversiteit, Gent, followed by counting of short- and long-lived product radionuclides. The determination of $\mathrm{Mn}, \mathrm{Ni}$, $\mathrm{Cu}, \mathrm{Zn}, \mathrm{Se}, \mathrm{Cd}$ and $\mathrm{Hg}$ were based on the $(\mathrm{n}, \gamma)$ reaction. This procedure was applied to ${ }^{56} \mathrm{Mn},{ }^{65} \mathrm{Ni},{ }^{66} \mathrm{Cu},{ }^{65} \mathrm{Zn},{ }^{74} \mathrm{Se},{ }^{115} \mathrm{Cd}$ and ${ }^{203} \mathrm{Hg}$.

The decays during the measurements and the dead time losses in the multi-channel analyzer were taken into account.

\section{Results and Discussion}

Except for major constituents in hair, not all the elements could be determined for every sample analysed. The ranges, arithmetic and geometric means and the medians were obtained from samples which showed detectable contents. These values are compiled in Table 1. It should be noticed that arithmetic and geometric means and medians obtained from samples which are restricted to those containing more than detection limits of corresponding elements will tend to overestimate the real values because contents under the detection limits are not taken into account.

Table 1 presents the hair trace element concentrations of $\mathrm{Mn}, \mathrm{Ni}, \mathrm{Cu}, \mathrm{Zn}, \mathrm{Se}, \mathrm{Cd}$ and $\mathrm{Hg}$ for the diabetic patients and for the control group. The arithmetic mean, geometric mean and median value for $\mathrm{Cu}, \mathrm{Zn}$ and $\mathrm{Hg}$ in the diabetic patients are about 3,3 and 7 times lower than the corresponding values in the control group, respectively. For Se in the patients in about 4.5 times higher than the corresponding value in the control group. Our results for $\mathrm{Mn}, \mathrm{Ni}$ and $\mathrm{Cd}$ shows that, no significiant changes in the hair concentrations of these elements. All element concentrations were $7 \%$ lower in female than in male, and there was no difference in levels among different age groups. These results could be used 
Table 1 Elemental concentration ( $\mathrm{ppm}$ ) in hair of control subjects and patients

\begin{tabular}{|c|c|c|c|c|c|c|}
\hline Element & Subject ${ }^{a}$ & $S e x^{b)}$ & Range & $\begin{array}{l}\text { Arithmetic mean } \\
\pm \text { standard deviation }\end{array}$ & $\begin{array}{l}\text { Geometric mean } \\
\text { /standard deviation }\end{array}$ & Median \\
\hline \multirow[t]{4}{*}{$\mathrm{Mn}$} & \multirow[t]{2}{*}{$\mathrm{C}$} & M & $0.15-5.7$ & $1.22 \pm 2.38$ & $0.86 / 2.1$ & 0.70 \\
\hline & & $\mathrm{F}$ & $0.14-5.4$ & $1.20 \pm 1.30$ & $0.87 / 2.5$ & 0.63 \\
\hline & \multirow[t]{2}{*}{$\mathrm{P}$} & M & $0.19-8.3$ & $1.56 \pm 2.30$ & $0.79 / 1.8$ & 0.62 \\
\hline & & $\mathrm{F}$ & $0.17-8.0$ & $1.48 \pm 2.10$ & $0.74 / 2.2$ & 0.58 \\
\hline \multirow[t]{4}{*}{$\mathrm{Ni}$} & \multirow[t]{2}{*}{$\mathrm{C}$} & M & $1.0-32.8$ & $8.80 \pm 15.3$ & $3.9 / 1.1$ & 3.70 \\
\hline & & $\mathrm{F}$ & $0.95-33.2$ & $8.20 \pm 14.8$ & $3.7 / 1.9$ & 3.40 \\
\hline & \multirow[t]{2}{*}{$\mathrm{P}$} & M & $0.97-38.0$ & $9.10 \pm 11.8$ & $3.5 / 2.1$ & 3.13 \\
\hline & & $\mathrm{F}$ & $0.93-36.0$ & $8.50 \pm 15.1$ & $3.1 / 2.0$ & 2.85 \\
\hline \multirow[t]{4}{*}{$\mathrm{Cu}$} & \multirow[t]{2}{*}{$\mathrm{C}$} & M & $8.0-25.0$ & $13.0 \pm 2.90$ & $11.5 / 1.1$ & 9.90 \\
\hline & & $\mathrm{F}$ & $7.3-23.0$ & $12.0 \pm 3.60$ & $10.3 / 1.5$ & 8.95 \\
\hline & \multirow[t]{2}{*}{$\mathrm{P}$} & M & $2.0-5.80$ & 4. $10 \pm 3.30$ & $3.8 / 1.6$ & 3.10 \\
\hline & & $\mathrm{F}$ & $1.9-5.50$ & $3 . \ddot{8} 3 \pm 4.20$ & $3.6 / 1.4$ & 2.96 \\
\hline \multirow[t]{4}{*}{$\mathrm{Zn}$} & \multirow[t]{2}{*}{$\mathrm{C}$} & M & $95-322$ & $188 \pm 40$ & $172 / 1.3$ & 178 \\
\hline & & $\mathrm{F}$ & $85-294$ & $174 \pm 42$ & $159 / 1.3$ & 164 \\
\hline & \multirow[t]{2}{*}{$\mathrm{P}$} & M & $14-54$ & $27 \pm 8$ & $25 / 1.5$ & 26 \\
\hline & & $\mathrm{F}$ & $12.5-47$ & $24 \pm 7$ & $22 / 1.6$ & 23 \\
\hline \multirow[t]{4}{*}{$\mathrm{Se}$} & \multirow[t]{2}{*}{$\mathrm{C}$} & $\mathrm{M}$ & $0.5-5.6$ & $0.83 \pm 0.63$ & $0.74 / 1.5$ & 0.66 \\
\hline & & $\mathrm{F}$ & $0.46-5.2$ & $0.77 \pm 0.62$ & $0.64 / 1.7$ & 0.60 \\
\hline & \multirow[t]{2}{*}{$\mathrm{P}$} & M & $2.0-26.0$ & $3.70 \pm 1.10$ & $3.1 / 1.4$ & 3.60 \\
\hline & & $\mathrm{F}$ & $1.86-24.2$ & $3.44 \pm 1.70$ & $2.9 / 1.8$ & 3.34 \\
\hline \multirow[t]{4}{*}{$\mathrm{Cd}$} & \multirow[t]{2}{*}{$\mathrm{C}$} & M & $0.18-9.8$ & $1.52 \pm 3.10$ & $0.94 / 1.8$ & 0.82 \\
\hline & & $\mathrm{F}$ & $0.16-9.2$ & $1.50 \pm 3.10$ & $0.85 / 1.9$ & 0.74 \\
\hline & \multirow[t]{2}{*}{$\mathrm{P}$} & M & $0.21-9.7$ & $1.54 \pm 2.30$ & $0.96 / 1.5$ & 0.85 \\
\hline & & $\mathrm{F}$ & $0.20-9.1$ & $1.50 \pm 2.20$ & $0.90 / 1.5$ & 0.79 \\
\hline \multirow[t]{4}{*}{$\mathrm{Hg}$} & \multirow[t]{2}{*}{$\mathrm{C}$} & M & $1.10-4.80$ & $2.30 \pm 0.70$ & $1.98 / 1.2$ & 2.10 \\
\hline & & $\mathrm{F}$ & $1.02-4.4$ & $2.12 \pm 0.30$ & $1.92 / 1.6$ & 1.98 \\
\hline & \multirow[t]{2}{*}{$\mathrm{P}$} & M & $0.36-1.6$ & $0.74 \pm 0.20$ & $0.69 / 1.7$ & 0.70 \\
\hline & & $\mathrm{F}$ & $0.34-1.5$ & $0.70 \pm 0.22$ & $0.64 / 1.6$ & 0.65 \\
\hline
\end{tabular}

a) $\mathrm{C}:$ control and $\mathrm{P}:$ patients

b) $\mathrm{M}:$ male and $\mathrm{F}:$ female

to diagnose the early stage of diabetes, but we hope that further studies will verify our findings.

\section{Acknowledgment}

The author is indebted to Prof. J. Hoste and Prof. R. Dams for accepting me as a guest. $\mathrm{He}$ is also grateful to the staff of the Thetis reactor for their assistance with the irradiations. He would like to thank Dr. A. Elkrsh and his assistants, Agiad Hospital, Mekka, Saudi Arabia for providing the hair samples and information on them.

\section{References}

1) Sugawara, N. and Chen, Bing-Qing: Res. Commun. Chem. Pathol. Pharmacol., 67, (3) 387 (1990)

2) D'Haese, P.C., Clement, J.P., Elseviers, M.M., Lamberts, L.V., Vande Vyver, F.L. and De Broe, M.E.: Nephrol. Dial. Transpl., 5, (1) 45 (1990)

3) Elnimr, T., Rofail, N.B. and Hassan, A.M.: Arabian J. Sci. Eng., 14, (3) 447 
(1989)

4) Sugawara, N., Hirohata, Y. and Sugawara, C.: J. Environ. Pathol. Toxicol. Oncol., 9, (1) 53 (1989)

5) Duflou, H., Maenhaut, W. and De Reuck, J.: Trace Elem. Anal. Chem. Med. Biol., 5, 484 (1988)

6) Ackrill, P. and Day, J.P.: Clin. Nephrol., 24, (1) S 94 (1985)

7) Elnimr, T., El-Hussainy, F., Motaweh, H.A., Elassaly, F.M., Rofail, N.B. and Hassan, A.M.: Egyptian J. Phys., (1990) in press

8) Elnimr, T. and Elhussany, F.: J. Phys. D, Appl. Phys., 18, 1967 (1985)

9) Elnimr, T. and Bondouk, I.I.: ibid., 16, 1407 (1983)

10) Elnimr, T.: ibid., 23, (10) 1278 (1990)
11) Moens, L., De Donder, J., Xilei, L., De Corte, F., De Wispelaere, A., Simonits, A. and Hoste, J.: Nucl. Instrum. Meth., 187, 187 (1981)

12) Jovanvoic, S., De Corte, F., Simonts, A., Moens, L., Vukotic, P. and Hoste, J.: Proc. 7 th Modern Trends in Activation Analysis (Copenhagen) June 23-27 (1986), Vol. 1, 613 (1986)

13) Moens, L., De Corte, F., Simonits, A., De Wispelaere, A. and Hoste, J.: J. Radioanal. Chem., 52, 379 (1979)

14) Chernick, J. and Vernon, R.: Nucl. Sci. Eng., 4, 649 (1958)

15) IAEA: Activation Analysis of Hair as an Indicator of Contamination of Man of Environ. Trace Poll. Rep. IAEA/RL/ 50, Vienna (1978) 